\title{
Appraisal patterns of envy and related emotions
}

\author{
Niels van de Ven • Marcel Zeelenberg • \\ Rik Pieters
}

Published online: 10 July 2011

(c) The Author(s) 2011. This article is published with open access at Springerlink.com

\begin{abstract}
Envy is a frustrating emotion that arises from upward social comparison. Two studies investigated the appraisals that distinguish benign envy (aimed at improving one's own situation) from malicious envy (aimed at pulling down the superior other). Study 1 found that appraisals of deservingness and control potential differentiated both types of envy. We manipulated these appraisals in Study 2 and found that while both did not influence the intensity of envy, they did determine the type of envy that resulted. The more a situation was appraised as undeserved, the more participants experienced malicious envy. Benign envy was experienced more when the situation was not undeserved, and the most when the situation was appraised as both deserved and controllable. The current research also clarifies how the types of envy differ from the related emotions admiration and resentment.
\end{abstract}

Keywords Envy · Appraisals · Deservingness - Control potential - Social comparisons $\cdot$ Admiration $\cdot$ Resentment

\section{Introduction}

Envy is a powerful emotion that "arises when a person lacks another's superior quality, achievement, or

N. van de Ven $(\bowtie) \cdot$ M. Zeelenberg

Department of Social Psychology, TIBER (Tilburg Institute for Behavioral Economics Research), Tilburg University, P.O. Box 90153, 5000LE Tilburg, The Netherlands

e-mail: N.v.d.Ven@tilburguniversity.edu

R. Pieters

Department of Marketing, TIBER (Tilburg Institute for Behavioral Economics Research), Tilburg University,

Tilburg, The Netherlands possession and either desires it or wishes that the other lacked it" (Parrott and Smith 1993, p. 906). Scholars have argued that only a malicious form of envy aimed at derogating the envied person should be considered "envy proper" (Miceli and Castelfranchi 2007; Schoeck 1969; Smith 2004; Smith and Kim 2007). Parrott (1991), however, made a case to also consider the existence of a nonmalicious form of envy. Such a distinction between malicious and benign envy could help to explain why envy activates both a desire to hurt the envied other and to a motivation to do better (Cohen-Charash 2009; Schaubroeck and Lam 2004).

Recent research indeed confirms that there are two types of envy: benign envy, a non-malicious form aimed at improving one's own situation, and malicious envy aimed at pulling down the envied person. Across several cultures, these two envy types have distinct experiential contents (Van de Ven et al. 2009). That is, they differ in the feelings, thoughts, action tendencies, and motivational goals that comprise the emotional experience. Benign and malicious envy thus differ on all phenomenological aspects. Moreover, these distinct envy types have idiosyncratic behavioral implications, underscoring the relevance of this distinction (Van de Ven et al. 2010, 2011a, b). However, little is known about the specific appraisal processes that determine when people will feel benign or malicious envy and subsequently become motivated to behave constructively or destructively.

The current goal is thus to reveal the appraisal patterns of benign and malicious envy and in particular those appraisals that shed light on the differences of these highly related emotions. We chose to examine these appraisals in the context of related social comparison emotions: admiration and resentment. This not only provides insight into when each emotion is likely to occur, but also helps to 
predict people's behavior as these various emotions activate different goals and action tendencies (Frijda 1986; Zeelenberg et al. 2008). Because benign and malicious envy have such different consequences (increasing motivation to do better versus hostile behavior aimed at pulling down the superior person) finding what elicits them seems indeed very important. We now first discuss the literature regarding appraisals, before we go into the predictions we make regarding the appraisals for benign envy, malicious envy, admiration, and resentment.

\section{Appraisal theory}

Appraisal theory is one of the most influential approaches to emotion (see for a review, Scherer et al. 2001). The core idea in appraisal theory is that each emotion can be related to a specific pattern of appraisals, which are cognitions about the perceived antecedents of emotional experiences. Here we adopt the approach of Roseman et al. (1996) that is derived from several different appraisal theories (Frijda 1986; Lazarus 1991; Roseman 1984; Scherer 1984; Smith and Ellsworth 1985; Weiner 1985). Roseman et al. differentiate the following appraisal dimensions: unexpectedness, motivational state, control potential, legitimacy, problem source, and agency (is the situation caused by the person him- or herself, by another person, or by the circumstances?). Table 1 displays the exact appraisals used in Study 1 . These dimensions have been shown to reliably differentiate even highly related emotions, such as regret and disappointment (Van Dijk and Zeelenberg 2002). We did not expect all of these appraisals to differ for benign and malicious envy, but to be complete in our exploratory analysis in Study 1 we included them all. Later in this introduction we will only discuss the appraisals for which we had specific hypotheses.

We added one additional appraisal dimension that seemed appropriate in this context: deservingness. Deservingness refers to whether the outcome for oneself or another is contingent on the situation: if there is a fit between the situation and the outcome it is deserved, else it is undeserved (Feather 1999). A student who studied hard and gets a good grade is perceived to deserve it (as the situation of studying hard is consistent with getting a good grade), while a situation in which a student who cheated gets a good grade is perceived to be undeserved. Prior envy research regularly found that subjective unfairness is related to envy (Smith 1991; Smith et al. 1994), but that research did not differentiate benign from malicious envy. We will detail why we added this dimension in the next section, where we explain our hypotheses.

The appraisal patterns of benign and malicious envy

The envy literature already allows for several predictions concerning the specific appraisal dimensions for malicious and benign envy. Envy is found to arise when people are

Table 1 Appraisal dimensions measured in study 1

\begin{tabular}{|c|c|}
\hline Dimension & Item and scale anchors \\
\hline Unexpectedness & The event was expected (1) to The event was unexpected (9) \\
\hline Situational state & I believed that the event improved things (1) to I believed that the event made things worse (9)* \\
\hline $\begin{array}{l}\text { Motivational } \\
\text { state }\end{array}$ & I wanted to get or keep something pleasurable (1) to I wanted to get rid of or avoid something painful (9)* \\
\hline Probability & I was certain about the consequences of the event (1) to I was uncertain about the consequences of the event (9)* \\
\hline $\begin{array}{l}\text { Control } \\
\text { potential }\end{array}$ & $\begin{array}{l}\text { I thought that there was something I could do about the event (1) to I thought that there was nothing I could do about the event } \\
(9)^{*}\end{array}$ \\
\hline Legitimacy & I thought of myself as morally right (1) or I thought of myself as morally wrong (9)介 \\
\hline Own power & I felt that I was powerless (1) to I felt that I was powerful (9)* \\
\hline Problem source & $\begin{array}{l}\text { I thought that the event did not reveal the basic nature of someone or something (1) to I thought that the event did reveal the } \\
\text { basic nature of someone or something (9) }\end{array}$ \\
\hline \multicolumn{2}{|l|}{ Agency } \\
\hline Self & I thought that the event was not at all caused by me (1) to I thought that the event was very much caused by me (9) \\
\hline Other & $\begin{array}{l}\text { I thought that the event was not at all caused by someone else (1) to I thought that the event was very much caused by } \\
\text { someone else (9) }\end{array}$ \\
\hline Circumstances & $\begin{array}{l}\text { I thought that the event was not at all caused by circumstances beyond anyone's control (1) to I thought that the event was } \\
\text { very much caused by circumstances beyond anyone's control (9) }\end{array}$ \\
\hline Deservingness & I thought that the event was very undeserved (1) to I thought that the event was very deserved (9) \\
\hline
\end{tabular}

An asterisk* indicates that responses were reverse-coded before analysis. This table is adapted from Van Dijk and Zeelenberg (2002). The anchors described above always followed the stem: "My emotion was caused, because __ "., with the specific emotion of that inserted instead of the word emotion 
confronted with a superior other, in a domain that is important to their self-view, and if the other was initially similar to them (Salovey and Rodin 1984). Smith and colleagues (Smith 2000; Smith et al. 1994) clarified that someone should also perceive to have low control over the situation (making it difficult to change the situation), and feel that it is unfair that the other has the superior position. Where these studies did not differentiate benign and malicious envy, Van de Ven et al. (2009) content analyzed written personal experiences of malicious envy, benign envy, admiration, and resentment. That analysis confirmed that both benign and malicious envy contained explicit social comparisons ("she got a good grade while I did not"), whereas these were hardly ever present for episodes of admiration and resentment. Furthermore, for both envy types the social comparison other was likely to be similar to them and the domain in which the emotional event took place was likely to be important. Interestingly, the two dimensions Smith and colleagues theorized to be the main causes of envy, low control potential and perceived unfairness, appeared to be mainly present in stories about malicious envy, not in those of benign envy.

Although these results provide some direction as to where to expect differences in appraisals associated with benign and malicious envy, there are two reasons why such content coding of events is not sufficient to draw conclusions regarding the appraisals (Roseman et al. 1996). First, having external raters code the content of an episode is clearly not the same as asking individuals themselves what caused the emotion (Frijda 1993; Parkinson and Manstead 1992; Roseman et al. 1990). Second, recalled episodes might contain multiple emotions, and the coding may pick up all of these. As Roseman et al. (1996, p. 245) stated: "Unless the subject is instructed to specify the appraisals that are relevant to the primary emotion under investigation, appraisals relevant to other emotions may be reported, obscuring true appraisal-emotion relationships."

Given the different behaviors that benign and malicious envy are associated with, it is important to understand when each type of envy is elicited. As we explain below, we have reason to believe that benign and malicious envy will predominantly differ with respect to the perceived deservingness of the situation and whether people think they can do something about it (control potential).

How deservingness determines which type of envy is elicited

We expected that envy-eliciting situations in which another is undeservedly better off will elicit malicious envy, while situations in which another is deservedly better off are more likely to elicit benign envy. It is important to note that deservingness differs from entitlement, with the latter referring to lawful or contractual outcomes and the former to earned outcomes (Feather 2003). For example, a colleague might not deserve a promotion, but might be entitled to it based on the number of years he works for the company. The deservingness of the situation provides information as to which emotion will be elicited and thus seems important to add as one of the important appraisal dimensions (Feather 2006; Feather and McKee 2009). For example, a deserved positive outcome can lead to feelings of pride, while a similar but undeserved outcome can lead to feelings of guilt.

The potential relation between deservingness and envy has been proposed before, with several authors claiming that undeservingness is a key component of envy (BenZe'ev 1992; Ortony et al. 1988). Consistent with this are findings that subjective injustice is indeed related to typical envy experiences, such as depressive and hostile feelings (Smith et al. 1994). Envious people also became less cooperative towards someone who was undeservedly better off, but not when the advantage of the other was deserved (Parks et al. 2002). A clear link thus seems to exist between perceptions of undeservingness and the hostile component of envy. We therefore reason that upward comparisons with people who do not deserve the advantage will elicit malicious envy, while comparisons with those who deserve the advantage will elicit benign envy.

This is important to test, as these predictions are at odds with the (untested) predictions of others. Ben-Ze'ev (1990) reasoned that if an advantage of another person is perceived to be deserved, the resulting (undifferentiated) envy will be less intense, as there is less reason to feel frustrated because the other is just better. In contrast to this, Miceli and Castelfranchi (2007) theorize that the more deserved it is perceived to be that the other has something one lacks, the more intense the envy will be. After all, an envious person who is outperformed by someone who really is much better might feel especially frustrated. We, however, predict that the intensity of the emotional experience of envy will not be affected by the perceived deservingness of the situation, but that appraisals of deservingness determine whether malicious or benign envy is felt.

How control potential determines which type of envy is elicited

Control potential refers to the perceived ability to control or do something about the event. As early as 1597, Bacon already reasoned that envy would be strongest for those who feel they cannot improve their situation. Similarly, Rawls (1971) argued that envy would become hostile when people have no opportunity to act constructively. Others go even further and argue that low perceived control is a necessary condition for envy to occur (Ortony et al. 1988; 
Smith 1991). Note, however, that these authors limited their theorizing to what they referred to as "envy proper," which corresponds to malicious envy and explicitly not to benign envy. We predicted that appraisals of low control potential would elicit malicious envy, while appraisals of high control potential would elicit benign envy.

Discriminant validity: distinguishing envy

from adjacent emotions

Until now we have been emphasizing the differences in the appraisal patterns of benign and malicious envy. In what follows, we compare them with the closely related but different emotions admiration and resentment. In order to paint a complete portrait of the appraisal patterns of malicious and benign envy, we consider it important to investigate how these emotions differ from their close relatives. One could argue that benign envy resembles admiration, and that malicious envy resembles resentment. If we were to find clear differences between these emotions, it would be testimony to both the importance of studying envy and distinguishing benign from malicious envy.

\section{Admiration}

Admiration has been defined as the emotional response to non-moral excellence (Algoe and Haidt 2009). Although both benign envy and admiration are felt when people are confronted with a superior other, there is a strong indication that they are different experiences (Van de Ven et al. 2009). First, benign envy feels frustrating, while admiration is a pleasant feeling. Second, benign envy was found to lead to action tendencies aimed at improving one's own situation, while admiration was not. Still, some have argued that perhaps the benign type of envy is more akin to admiration than to what they consider "envy proper", namely malicious envy (Miceli and Castelfranchi 2007; Rawls 1971; Smith and Kim 2007). As such it is important to investigate what appraisals differ between envy and these related emotions.

The appraisal that we expected to differ most between benign envy and admiration is that of self-agency. We expected the self to be less involved for admiration than for benign envy. This would be consistent with our earlier content analysis (Van de Ven et al. 2009). In it, we found that benign envy, but not admiration, was related to explicit social comparisons (e.g., "I did not pass the exam, while the other person did"). It could also explain why admiration is a more pleasant emotion and benign envy is a frustrating one: if the upward comparison reflects badly on oneself frustration is more likely to occur. Because of this, we also expected the situation to have worsened somewhat for benign envy but not for admiration (predicting a difference for benign envy and admiration on the situational state appraisal). Finally, if the self is not involved for admiration, we expected that perceptions of having control over the situation would not be as important for admiration as they are for benign envy.

\section{Resentment}

Merriam Webster's dictionary defines resentment as the indignant displeasure or persistent ill will at something regarded as wrong. According to this definition, resentment is broader than envy and admiration, for which there must always be a superior other. Resentment can also be directed at institutions or at persons perceived to be in an inferior position. For example, people who feel that their situation is superior to that of people in a communist system, might still resent communists if they perceive the communist belief system to be morally wrong. In the current research, we asked participants to recall experiencing resentment for one specific person, as that is the resentment that is relatively close to malicious envy.

We expected that both malicious envy and resentment would be elicited in undeserved situations, but that they primarily differ with respect to appraisals of agency. Others have theorized that resentment is more likely if the situation is perceived to be objectively unfair (D'Arms 2009; Rawls 1971), while (malicious) envy is more likely if there is more of a subjective feeling of undeservingness (Feather and Sherman 2002; Smith et al. 1994). However, appraisal theory suggests that appraisals that lead to certain emotions are by definition subjective perceptions of the situation (Scherer et al. 2001). Furthermore, perceptions of fairness and deservingness are likely to be strongly related, making these unlikely candidates for differentiating envy from resentment.

Ben-Ze'ev (2002) argued that a core difference between envy and resentment is that the latter is caused by a perceived moral transgression, while the former is not. This implies that resentment would be elicited in situations in which the other is blamed for the immoral behavior that brought him or her in undeserved superior position, while for malicious envy this would not be the case. Thus, if the other person actually caused you to be worse off resentment is more likely, while malicious envy is more likely if situational factors are responsible. For example, a football player could be maliciously envious of another player who undeservedly made the first team if it was the decision of the coach to choose the other, but the football player would resent the other player if the other player had cheated with his playing record to get into the first team. We predicted that resentment exists if the other caused the event (the dimension of agency that measures whether the situation 
was caused by someone else) and that it thus truly revealed something about the nature of this other person, while malicious envy would exist if it were more the circumstances that had caused the event.

Taken together, we were interested in the appraisal patterns of benign and malicious envy and we studied them in the context of the related emotions admiration and resentment. In Study 1 we sampled personal experiences of benign envy, malicious envy, admiration, and resentment, and compared the appraisals that caused these emotional experiences. In Study 2 we examined whether manipulations of deservingness and control potential would differentially influence benign or malicious envy in participants. These studies help to show how benign and malicious envy differ from each other and from related emotions. Furthermore, they help to predict when people will become motivated to do better for themselves when confronted with a superior other person (when benign envy is elicited) and when people will become motivated to engage in hostile, destructive behavior (when malicious envy is elicited).

\section{Study 1}

Method

One hundred and thirty-six participants (112 females, $M_{\text {age }}=20$ years) were randomly distributed to either the Benign Envy, Malicious Envy, Admiration, or the Resentment condition, with 34 participants per condition. One participant from the resentment condition was excluded from the analyses, as she indicated to have never experienced it.

Participants arrived in the lab for a series of studies, of which ours was part. Depending on the condition, they recalled one of four personal experiences: benign envy, malicious envy, admiration, or resentment. Participants wrote briefly about how that experience had felt to them. After doing so, the participants were asked a series of questions designed to measure appraisals (see Table 1). We included the nine different appraisal dimensions adopted from Roseman et al. (1996) that were successfully used by Van Dijk and Zeelenberg (2002). We additionally included the appraisal item for deservingness (Feather and McKee 2009). Each appraisal item asked whether a particular appraisal had caused the participant to feel the emotion that was recalled. For example, an item assessing the extent to which an appraisal of deservingness had caused a participant to feel admiration was, "My admiration was caused because I thought that the event was very undeserved (1) ... I thought that the event was very deserved (9)". A detailed account of this procedure is provided by Roseman et al. (1996).
Participants rated the extent to which each appraisal had caused their emotion. Roseman et al. (1996) point out that it is important to specifically ask for the causes of the emotion under study for two reasons. First, rating the situation could lead to different responses than rating the causes of the emotion does (Frijda 1993; Parkinson and Manstead 1992; Roseman et al. 1990). Second, some recalled situations might actually contain several emotions, making it important to test the direct cause of the specific emotion under study.

\section{Results and discussion}

Table 2 shows the mean scores on each appraisal scale per emotion condition. These were entered into a MANOVA, using the recalled emotion as a between-subjects factor. Overall, a clear difference existed on the appraisals between the emotion conditions, $F(36,356)=5.07, p<.001$, $\eta_{\mathrm{p}}^{2}=.33$. We will first discuss the differences between benign and malicious envy, and then compare benign envy to admiration and malicious envy to resentment.

\section{Benign versus malicious envy}

Two differences existed for benign and malicious envy in the appraisals that elicited these emotions. First, and as expected, the perceived deservingness of the situation clearly mattered: For malicious envy, the situation was strongly perceived to be undeserved, while for benign envy this was not the case. Deservingness was thus clearly related to the type of envy elicited. Second, we also found a difference with respect to the appraisal of control potential. Those in the benign envy condition indicated that they had more control over the situation than those in the malicious envy condition. These two findings confirm our predictions.

\section{Benign envy versus admiration}

We predicted that for benign envy, but not for admiration, the recalled situation had reflected badly upon the participant. Consistent with this, participants indeed felt that they had caused the situation much less for admiration than for benign envy. They also indicated lower control potential with admiration than with benign envy, another indication that they were more involved for benign envy than for admiration. Also, they felt that the event worsened more for benign envy, and thus that the situation eliciting benign envy reflected badly upon them. Two other findings were that participants felt that the event had revealed more about the other for admiration than for benign envy, and that the event was even more strongly deserved for admiration than for benign envy. Both reflect the idea that for admiration it 
Table 2 Appraisal dimensions of admiration, benign envy, malicious envy, and resentment in study 1

\begin{tabular}{|c|c|c|c|c|c|c|c|c|c|c|c|}
\hline & \multicolumn{2}{|c|}{ Admiration } & \multicolumn{2}{|c|}{ Benign envy } & \multicolumn{2}{|c|}{$\begin{array}{l}\text { Malicious } \\
\text { envy }\end{array}$} & \multicolumn{2}{|c|}{ Resentment } & \multicolumn{3}{|l|}{ Statistics } \\
\hline & M & (SD) & M & (SD) & M & (SD) & M & (SD) & $F(3,132)$ & $p$ & $\eta_{\mathrm{p}}^{2}$ \\
\hline Unexpectedness (expected-unexpected) & 6.09 & $(1.91)$ & 6.03 & $(1.99)$ & 5.97 & $(2.26)$ & 6.42 & $(1.89)$ & .34 & .799 & .01 \\
\hline Situational state (worsened-improved) & $6.44^{\mathrm{a}}$ & $(1.78)$ & $4.44^{\mathrm{b}}$ & $(1.81)$ & $4.35^{\mathrm{b}}$ & $(1.86)$ & $3.42^{\mathrm{c}}$ & $(1.80)$ & 16.54 & .001 & .28 \\
\hline Motivational state (avoid—approach) & $6.82^{\mathrm{a}}$ & $(1.34)$ & $6.18^{\mathrm{ab}}$ & $(2.28)$ & $6.44^{\mathrm{ab}}$ & $(2.11)$ & $5.61^{\mathrm{b}}$ & $(2.45)$ & 2.02 & .115 & .04 \\
\hline Probability (uncertain-certain) & 5.12 & $(1.77)$ & 4.85 & $(2.09)$ & 5.06 & $(2.20)$ & 4.82 & $(2.05)$ & .18 & .910 & .00 \\
\hline Control potential (no control—control) & $4.03^{\mathrm{b}}$ & $(1.62)$ & $5.06^{\mathrm{a}}$ & $(2.32)$ & $4.06^{\mathrm{b}}$ & $(1.77)$ & $3.91^{\mathrm{b}}$ & $(2.23)$ & 2.40 & .071 & .05 \\
\hline Legitimacy (morally wrong—right) & $5.56^{\mathrm{b}}$ & $(1.38)$ & $5.91^{\mathrm{ab}}$ & $(1.71)$ & $6.59^{\mathrm{a}}$ & $(1.93)$ & $7.55^{\mathrm{a}}$ & $(1.60)$ & 9.21 & .001 & .17 \\
\hline Own power (powerful—powerless) & $6.09^{\mathrm{b}}$ & $(1.53)$ & $6.76^{\mathrm{ab}}$ & $(1.52)$ & $6.94^{\mathrm{a}}$ & $(1.56)$ & $7.09^{\mathrm{a}}$ & (1.94) & 2.45 & .066 & .05 \\
\hline $\begin{array}{l}\text { Problem source (did not reveal true nature- } \text { did } \\
\text { reveal) }\end{array}$ & $6.59^{\mathrm{a}}$ & $(1.46)$ & $5.44^{\mathrm{b}}$ & $(2.27)$ & $5.43^{\mathrm{b}}$ & $(2.22)$ & $6.12^{\mathrm{a}}$ & $(1.67)$ & 10.83 & .001 & .20 \\
\hline \multicolumn{12}{|l|}{ Agency } \\
\hline Self (not by self-by self) & $3.18^{\mathrm{a}}$ & $(1.88)$ & $4.21^{\mathrm{b}}$ & $(1.86)$ & $3.65^{\mathrm{ab}}$ & $(1.89)$ & $3.21^{\mathrm{a}}$ & $(1.92)$ & 2.20 & .091 & .05 \\
\hline Other (not by other-by other) & $5.82^{\mathrm{a}}$ & $(2.24)$ & $5.62^{\mathrm{a}}$ & $(1.91)$ & $5.88^{\mathrm{a}}$ & $(2.19)$ & $7.09^{b}$ & $(1.67)$ & 3.66 & .014 & .08 \\
\hline Circumstances(not circumstances-circumstances) & $4.47^{\mathrm{b}}$ & $(2.43)$ & $4.79^{\mathrm{b}}$ & $(2.25)$ & $5.00^{\mathrm{b}}$ & $(2.22)$ & $3.09^{\mathrm{a}}$ & $(2.16)$ & 4.80 & .003 & .10 \\
\hline Deservingness (undeserved-deserved) & $6.74^{\mathrm{c}}$ & $(2.47)$ & $4.56^{\mathrm{b}}$ & $(2.36)$ & $2.50^{\mathrm{a}}$ & $(1.66)$ & $2.52^{\mathrm{a}}$ & $(1.77)$ & 31.34 & .001 & .42 \\
\hline
\end{tabular}

Means with different superscripts differ at $p<.05$, tested with LSD post hoc tests

are the qualities of the other person that are central, not how this reflects on the person experiencing the emotion.

\section{Malicious envy versus resentment}

Resentment was elicited more in unfair situations attributed to the willful behavior of the other, while malicious envy was thought to exist more if there was a subjective experience of undeservingness caused by the circumstances. Consistent with this, we found that resentment existed if the events were attributed more to the behavior of the other person than for the events that elicited malicious envy. In turn, the events that elicited malicious envy were attributed more to the circumstances than the events that elicited resentment were. Furthermore, the events that caused resentment also truly revealed something about the other person more than those that elicited malicious envy. This all suggests that resentment exists more if the other is to blame whereas malicious envy exists more if the situational circumstances are to blame. Finally, we also found that events that elicited resentment had worsened the situation for the participant even more than the events causing malicious envy.

Study 1 thus suggests that admiration is more likely if being outperformed does not reflect badly on oneself. If it does reflect badly upon oneself, but the situation is deserved, benign envy is likely to result. If it is undeserved, however, which emotion is elicited depends on who is to blame. If the person who is better off is to blame, resentment will occur, while if the circumstances are more to blame malicious envy is likely to be elicited. In Study 2 we examined the appraisals that lead to benign and malicious in a controlled setting.

\section{Study 2}

Study 2 manipulates the appraisals of deservingness and coping potential and tests whether this influences the elicitation of benign and malicious envy. We built upon the findings of Study 1 to make sure that admiration and resentment are not likely to be elicited. A key difference between malicious envy and resentment is whether the other is blamed for the situation (which leads to resentment) or whether the circumstances are blamed (leading to malicious envy). We therefore created situations in which the other was not objectively to blame for the situation. Second, in order not to elicit admiration, we created situations in which the upward comparison reflects (somewhat) negatively on the participant.

\section{Method}

One hundred and twenty-four participants (75 females, $M_{\text {age }}=20$ years) were randomly assigned to one of the conditions of a 2 (Deservingness: Undeserved vs. Deserved) $\times 2$ (Control Potential: Low vs. High) design (with $n=30-32$ per condition). Participants read a scenario in which a coworker received a raise while the participant did not. This raise was either undeserved (because 
the coworker reels in less clients) or it was deserved (because the coworker reels in more clients). Control Potential was manipulated by providing information that the next evaluation for a possible raise is in a year (Low Control) or that the next possibility was already in 3 months (High Control). An example of the scenario (the Low Control and Undeserved condition) is:

You and some fellow students are working in a call center to earn some extra money. The call center is part of a big office supplier and targets large companies. It is your job to contact existing clients for new orders, and to reel in some new clients.

As performance is importance for management, everyone is evaluated on a yearly basis, and your wage for the upcoming year is determined based on this evaluation. Last week the evaluations took place and your new wage is set.

There is one thing that frustrates you: One of your coworkers, whom you often hang out with and get along with reasonably well, ends up receiving a higher wage than you, despite the fact that the evaluation actually shows that your coworker reels in less clients and also sells less.

Next, the participants responded to a number of questions. As manipulation checks we asked participants whether they had felt that the situation was deserved $(-3$ undeserved; +3 deserved), and whether they would have felt control over the situation $(-3$ definitely not; +3 definitely so). The overall intensity of the envy was assessed by "how jealous would you be towards your coworker" $(0=$ not at all, $8=$ very much so; these scale anchors were also used for the other questions), which we did not predict to differ across the conditions. We asked for jealousy instead of envy, because this term is most often used in colloquial language (Smith et al. 1988), and because the
Dutch language does not have one single word for both types of envy as for example the English language does. Benign and malicious envy were measured with two questions each, based on differences in their experiential content (Van de Ven et al. 2009). Benign envy was assessed by asking whether they "would be inspired" and "would start to work harder," $r(124)=.46, p<.001$. Malicious envy was assessed by asking whether they "would secretly wish that their coworker would lose clients" and "would gossip about the coworker to others", $r(124)=.40, p<.001$.

Results and discussion

\section{Manipulation checks}

The results are shown in Table 3. As predicted, the ratings of the jealousy felt towards the coworker were similar across conditions, all $F^{\prime} \mathrm{s}<1, M=4.31, \mathrm{SD}=2.14$, indicating that the manipulations did not influence the intensity of the experienced envy which is what we expected (as we did not expect differences in the intensity of the envy elicited, but only of the type of envy that would be elicited).

The manipulations worked as intended. The perceived deservingness of the situation was only influenced by the manipulation of Deservingness, $F(1,120)=179.16$, $p<.001, \eta_{\mathrm{p}}^{2}=.60$, and not by the manipulation of Control Potential nor the interaction of the two manipulations, $F$ 's $<1$. Those in the Undeserved conditions found the situation to be less deserved $(M=-2.15, \mathrm{SD}=.90)$ than those in the Deserved conditions $(M=1.09, \mathrm{SD}=1.61)$.

Perceived control was influenced by the manipulation of Control Potential, $F(1,120)=6.23, p=.014, \eta_{\mathrm{p}}^{2}=.05$. Those in the Low Control conditions perceived to have less control $(M=.16, \mathrm{SD}=1.90)$ than those in the High Control condition $(M=.82, \mathrm{SD}=1.80)$. An unexpected

Table 3 Manipulation checks and types of envy per condition in study 2

\begin{tabular}{|c|c|c|c|c|c|}
\hline & \multirow[b]{3}{*}{ Control potential } & \multicolumn{4}{|c|}{ Deservingness } \\
\hline & & \multicolumn{2}{|c|}{ Undeserved } & \multicolumn{2}{|c|}{ Deserved } \\
\hline & & M & (SD) & M & (SD) \\
\hline \multirow[t]{2}{*}{ Deservingness } & Low control & -2.23 & $(.90)$ & 1.12 & $(1.45)$ \\
\hline & High control & -2.00 & $(1.27)$ & 1.13 & $(1.65)$ \\
\hline \multirow[t]{2}{*}{ Perceived control } & Low control & -.37 & $(1.79)$ & .50 & (1.98) \\
\hline & High control & .03 & (1.99) & 1.71 & (1.32) \\
\hline \multirow[t]{2}{*}{ Malicious envy } & Low control & 3.93 & $(1.80)$ & 2.95 & $(1.76)$ \\
\hline & High control & 4.06 & $(2.13)$ & 2.29 & (1.54) \\
\hline \multirow[t]{2}{*}{ Benign envy } & Low control & 3.58 & $(1.54)$ & 4.94 & $(1.75)$ \\
\hline & High control & 3.53 & $(3.22)$ & 5.94 & $(1.33)$ \\
\hline
\end{tabular}


effect emerged for the deservingness manipulation on perceived control, $F(1,120)=15.57, p<.001, \eta_{\mathrm{p}}^{2}=.12$. Those in the Undeserved conditions perceived to have less control $(M=-.07, \mathrm{SD}=1.92)$ than those in the Deserved conditions $(M=1.15, \mathrm{SD}=1.67)$. There was no interaction effect of the two manipulations on perceived control, $F(1,120)=1.58, p=.211, \eta_{\mathrm{p}}^{2}=.01$. The unexpected effect of the Deservingness manipulation on perceived control seems likely to be caused by the uncertainty of the situation: if another person can actually receive a benefit when performing badly, there is also the risk that one is not rewarded after performing well. In this way, an undeserved outcome might also indicate a lower perceived control.

\section{Benign and malicious envy}

As can be seen in Table 3, the manipulations clearly affected the type of envy elicited. We performed an analysis with the two manipulations as independent variables, and the two types of envy as a within-subjects variable. First, a main effect for the type of envy existed, $F(1$, $120)=27.62, p<.001, \eta_{\mathrm{p}}^{2}=.19$, indicating that people reported higher levels of benign envy $(M=5.43$, $\mathrm{SD}=1.62)$ than of malicious envy $(M=2.63$, $\mathrm{SD}=1.68$ ). It could be the case that this effect exists because people do not like to admit being maliciously envious, neither to themselves nor to others (Foster 1972) and that the behavior following malicious envy are rather socially undesirable responses.

For the manipulation of deservingness, an interaction existed between that manipulation and the intensity of the envy types, $F(1,120)=51.97, p<.001, \eta_{\mathrm{p}}^{2}=.30$. This interaction confirms that malicious envy was present more when the situation was undeserved $(M=3.96, \mathrm{SD}=2.06)$ than when it was deserved $(M=2.48, \mathrm{SD}=1.70, F(1$, $120)=17.73, p<.001, \eta_{\mathrm{p}}^{2}=.13$ ), while benign envy is experienced more if the situation is perceived to be deserved $(M=5.37, \quad \mathrm{SD}=1.64) \quad$ than undeserved $(M=3.22, \quad \mathrm{SD}=1.76, \quad F(1,120)=41.17, \quad p<.001$, $\left.\eta_{\mathrm{p}}^{2}=.26\right)$.

For the manipulation of control potential no main effect existed, $F(1,120)=2.68, p=.104, \eta_{\mathrm{p}}^{2}=.02$. There was a three-way interaction between the two manipulations and the envy types, however, $F(1,120)=4.16, p=.044$, $\eta_{\mathrm{p}}^{2}=.03$. Closer inspection of the means revealed that this three-way interaction arose because the manipulation of Control Potential did not influence the envy types when the situation was undeserved, $F<1$, but it did when the situation was deserved, $F(1,61)=8.03, p=.006, \eta_{\mathrm{p}}^{2}=.12$. When the situation was deserved, the participants in the High Control condition experienced more benign envy $(M=5.94, \mathrm{SD}=1.33)$ than those in the Low Control condition $(M=4.94, \mathrm{SD}=1.75, F(1,61)=6.48, p=$ $\left..013, \eta_{\mathrm{p}}^{2}=.10\right)$.

To conclude, we found that an upward social comparison situation that is deserved elicits benign envy, while one that is undeserved elicits malicious envy. Appraisals of control potential were only related to benign envy, and only in deserved situations. A possible reason for this could be that the manipulation of deservingness also unintentionally influenced perceived control: if it was really undeserved that someone else got a raise, the selection of who gets a raise seems more random and the perceived control becomes lower as well. To test the influence of perceived deservingness and control potential independently, we tested effects of the manipulation checks on both types of envy. This analysis found that for malicious envy, only deservingness had an effect, $\beta=-.45$, $p<.001$, while perceived control had not, $\beta=-.01$, $p=.974$. For benign envy, however, both deservingness, $\beta=.43, \quad p<.001$, and perceived control, $\beta=.22$, $p=.008$, had an effect.

The experiences of benign and malicious envy were negatively correlated, $r(124)=-.25, p=.006$, such that the more a person experiences one type of envy, the less the other type was experienced. This supports that these two types of envy are not simply both reflections of the same underlying envy emotion, but are qualitatively different. As reported before, the overall intensity of the emotion reported by participants was similar across all conditions, suggesting that only the type of envy differed between conditions. Thus, the general intensity of the emotion is not influenced by the perceived deservingness, which contradicts the predictions that deservingness might lead to less (Ben-Ze'ev 1990) or more (Miceli and Castelfranchi 2007) envy, rather it is the type of envy that is influenced by perceptions of deservingness.

\section{General discussion}

The current results confirm our prediction that appraisals of deservingness and control potential are important in the shaping of the emotional experiences of benign and malicious envy. These results came from two studies, one using recalled life-events and assessing appraisal patterns, the other using an experimental design in which appraisals were manipulated and emotions were assessed. The results are important because they provide insight into when benign envy exists that leads to constructive behavior aimed at moving up to the superior position, and when malicious envy exists that leads to destructive behavior aimed at pulling down the envied person.

The difference in events that elicit malicious envy or resentment can be found in who is to blame for the 
undeserved situation: if the other is to blame resentment will be elicited, if the circumstances are to blame than malicious envy is more likely. This also explains why earlier work found that resentment gives rise to more objective feelings of unfairness and malicious envy to subjective feelings of undeservingness (Smith et al. 1994).

Undeserved situations elicited malicious envy, but it was not the case that the events that led to benign envy were strongly deserved. Rather, it seemed that situations with upward comparisons that reflect bad on oneself that are not perceived to be undeserved lead to benign envy. Furthermore, although there are likely to be more factors that could influence whether benign or malicious envy is elicited in certain situations, we think that these other factors will have an influence via deservingness. For example, it seems likely that a person more easily becomes maliciously envious towards a disliked person. We predict this to be the case because an advantage of a disliked person could easily be perceived as undeserved.

The finding that the perception that malicious envy was not influenced by the perception of control over the situation, but that benign envy was is an intriguing one. This effect is likely to exist because in the undeserved situation in our Study 2 the perceived control also became lower (if it is undeserved when people are rewarded, one could also be not rewarded if one does well, reflecting lowered control). This could reflect an issue with our scenario, but we do wish to note that this confounding of undeservingness and control potential seems to be present in all undeserved situations: undeserved situations by definition constitute of a discrepancy between what someone put into a situation and what they got out of it (Feather 1999). Another possibility, however, is that perhaps the perceived control is a consequence of experiencing benign envy instead of an appraisal that led to benign envy. We explicitly asked participants whether the control potential caused the benign envy and not the other way around in Study 1 (the benign envy was caused because I thought that I could do something about the event"). However, a possibility exists that benign envy leads to a motivation to improve one's own position and thereby also to a greater perception of control over the situation ("I want to improve, and I think I can"). Given how we assessed control potential this seems unlikely, but we cannot fully rule out this interpretation.

Finding the appraisals that distinguish between the two types of envy also provides insight into who might be more prone to experiencing each type of envy. People who tend to feel entitled to many things (Campbell et al. 2004) may also find it undeserved when others have an advantage over them. These are thus expected to more often and more intensely experience malicious envy instead of benign envy. In contrast, people with a high "belief in a just world" (Rubin and Peplau 1975) feel that people generally get what they deserve and are therefore expected to experience benign envy more easily in envy situations. Furthermore, people with an internal locus of control (Duttweiler 1984) tend to feel that they can easily influence situations themselves, and might thus be especially likely to experience benign envy. Investigating which persons are likely to become hostile or who become inspired after being confronted with others who outperform them seems an interesting line of study.

We also compared how benign and malicious envy differed from the related emotions admiration and resentment. All these emotions are generally elicited by being confronted with someone who is better off, but their experiences and the behavior they lead to are very different. We found that benign envy and admiration mainly differ on whether the comparison reflects badly on oneself; when it does benign envy is elicited if it does not admiration is. For benign envy people felt that the situation had worsened more than it had for admiration, and the situation was perceived to have been caused more by oneself. It thus seems that for benign envy the good performance of another person is evaluated compared to that of oneself. In his model of social comparison emotions, Smith (2000) called this a dual focus for envy (on both oneself and the other), while the focus of admiration lies only on the other person.

The current research investigated which appraisals differentiate benign and malicious envy. The core finding that the deservingness of the situation matters the most, gives us an important insight into harnessing the potential destructiveness of envy, and to perhaps even turn it into something good. Evaluating the positive outcomes of someone else as deserved prevents possible negative behavior following envy, and is actually likely to inspire people to work harder and attain more for oneself.

Acknowledgment We thank Maikel Gorissen for his help in conducting the studies.

Open Access This article is distributed under the terms of the Creative Commons Attribution Noncommercial License which permits any noncommercial use, distribution, and reproduction in any medium, provided the original author(s) and source are credited.

\section{References}

Algoe, S. B., \& Haidt, J. (2009). Witnessing excellence in action: The 'other-praising' emotions of elevation, gratitude, and admiration. Journal of Positive Psychology, 4(2), 105-127.

Bacon, F. (1597). Of envy. In The essays. Retrieved December 20, 2010, from http://www.westegg.com/bacon/envy.html.

Ben-Ze'ev, A. (1990). Envy and jealousy. Canadian Journal of Philosophy, 20(4), 487-516. 
Ben-Ze'ev, A. (1992). Envy and inequality. The Journal of Philosophy, 84(11), 551-581.

Ben-Ze'ev, A. (2002). Are envy, anger, and resentment moral emotions? Philosophical Explorations, 5(2), 148-154.

Campbell, W. K., Bonacci, A. M., Shelton, J., Exline, J. J., \& Bushman, B. J. (2004). Psychological entitlement: Interpersonal consequences and validation of a self-report measure. Journal of Personality Assessment, 83(1), 29-45.

Cohen-Charash, Y. (2009). Episodic envy. Journal of Applied Social Psychology, 39(9), 2128-2173.

D'Arms, J. (2009). Envy: The stanford encyclopedia of philosophy. Retrieved March 11 2010, from http://plato.stanford.edu/entries/ envy/\#1.3.

Duttweiler, P. C. (1984). The internal control index: A newly developed measure of locus of control. Educational and Psychological Measurement, 44(2), 209-221.

Feather, N. T. (1999). Judgments of deservingness: Studies in the psychology of justice and achievement. Personality and Social Psychology Review, 3(2), 86-107.

Feather, N. T. (2003). Distinguishing between deservingness and entitlement: Earned outcomes versus lawful concerns. European Journal of Social Psychology, 33(3), 367-385.

Feather, N. T. (2006). Deservingness and emotions: Applying the structural model of deservingness to the analysis of affective reactions to outcomes. European Review of Social Psychology, $17,38-73$.

Feather, N. T., \& McKee, I. R. (2009). Differentiating emotions in relation to deserved or undeserved outcomes: A retrospective study of real-life events. Cognition \& Emotion, 23(5), 955-977.

Feather, N. T., \& Sherman, R. (2002). Envy, resentment, schadenfreude, and sympathy: Reactions to deserved and undeserved achievement and subsequent failure. Personality and Social Psychology Bulletin, 28(7), 953-961.

Foster, G. M. (1972). The anatomy of envy: A study in symbolic behavior. Current Anthropology, 13(2), 165-202.

Frijda, N. H. (1986). The emotions. Cambridge, England: Cambridge University Press.

Frijda, N. H. (1993). The place of appraisal in emotion. Cognition and Emotion, 7(3-4), 357-387.

Lazarus, R. S. (1991). Progress on a cognitive-motivational-relational theory of emotion. American Psychologist, 46(8), 819-834.

Miceli, M., \& Castelfranchi, C. (2007). The envious mind. Cognition and Emotion, 21(3), 449-479.

Ortony, A., Clore, G. L., \& Collins, A. (1988). The cognitive structure of emotions. New York: Cambridge University Press.

Parkinson, B., \& Manstead, A. S. R. (1992). Appraisal as a cause of emotion. In M. S. Clark (Ed.), Review of personality and social psychology (pp. 122-149). Newbury Park, CA: Sage.

Parks, C. D., Rumble, A. C., \& Posey, D. C. (2002). The effects of envy on reciprocation in a social dilemma. Personality and Social Psychology Bulletin, 28(4), 509-520.

Parrott, W. G. (1991). The emotional experiences of envy and jealousy. In P. Salovey (Ed.), The psychology of jealousy and envy (pp. 3-30). New York: Guilford Press.

Parrott, W. G., \& Smith, R. H. (1993). Distinguishing the experiences of envy and jealousy. Journal of Personality and Social Psychology, 64(6), 906-920.

Rawls, J. (1971). A theory of justice. Cambridge, MA: Harvard University Press.

Roseman, I. J. (1984). Cognitive determinants of emotions: A structural theory. In P. Shaver (Ed.), Review of personality and social psychology (Vol. 5, pp. 11-36). Newbury Park, CA: Sage.

Roseman, I. J., Antoniou, A. A., \& Jose, P. E. (1996). Appraisal determinants of emotions: Constructing a more accurate and comprehensive theory. Cognition and Emotion, 10(3), 241-277.
Roseman, I. J., Spindel, M. S., \& Jose, P. E. (1990). Appraisal of emotion-eliciting events: Testing a theory of discrete emotions. Journal of Personality and Social Psychology, 59(5), 899-915.

Rubin, Z., \& Peplau, A. (1975). Who believes in a just world? Journal of Social Issues, 31(3), 65-89.

Salovey, P., \& Rodin, J. (1984). Some antecedents and consequences of social comparison jealousy. Journal of Personality and Social Psychology, 47(4), 780-792.

Schaubroeck, J., \& Lam, S. S. K. (2004). Comparing lots before and after: Promotion rejectees' invidious reactions to promotees. Organizational Behavior and Human Decision Processes, 94, 33-47.

Scherer, K. R. (1984). Emotion as a multi-component process. In P. Shaver (Ed.), Review of personality and social psychology: Emotions, relationships, and health (pp. 37-63). Newbury Park, CA: Sage.

Scherer, K. R., Schorr, A., \& Johnstone, T. (2001). Appraisal processes in emotion: Theory, research, application. New York: Oxford University Press.

Schoeck, H. (1969). Envy: A theory of social behavior. New York: Harcourt, Brace and World.

Smith, R. H. (1991). Envy and the sense of injustice. In P. Salovey (Ed.), The psychology of envy and jealousy (pp. 79-99). New York: Guilford Press.

Smith, R. H. (2000). Assimilative and contrastive emotional reactions to upward and downward social comparisons. In J. Suls \& L. Wheeler (Eds.), Handbook of social comparison (pp. 173-200). New York: Kluwer Academic/Plenum Publishers.

Smith, R. H. (2004). Envy and its transmutations. In L. Z. Tiedens \& C. W. Leach (Eds.), The social life of emotions (pp. 43-63). Cambridge: Cambridge University Press.

Smith, C. A., \& Ellsworth, P. C. (1985). Patterns of cognitive appraisal in emotion. Journal of Personality and Social Psychology, 48(4), 813-838.

Smith, R. H., \& Kim, S. H. (2007). Comprehending envy. Psychological Bulletin, 133(1), 46-64.

Smith, R. H., Kim, S. H., \& Parrott, W. G. (1988). Envy and jealousy: Semantic problems and experiential distinctions. Personality and Social Psychology Bulletin, 14(2), 401-409.

Smith, R. H., Parrott, W. G., Ozer, D., \& Moniz, A. (1994). Subjective injustice and inferiority as predictors of hostile and depressive feelings in envy. Personality and Social Psychology Bulletin, 20(6), 705-711.

Van de Ven, N., Zeelenberg, M., \& Pieters, R. (2009). Leveling up and down: The experiences of benign and malicious envy. Emotion, 9(3), 419-429.

Van de Ven, N., Zeelenberg, M., \& Pieters, R. (2010). Warding off the evil eye: When the fear of being envied increases prosocial behavior. Psychological Science, 21(11), 1671-1677.

Van de Ven, N., Zeelenberg, M., \& Pieters, R. (2011a). The envy premium in product evaluation. Journal of Consumer Research, 37(6), 984-998.

Van de Ven, N., Zeelenberg, M., \& Pieters, R. (2011b). Why envy outperforms admiration. Personality and Social Psychology Bulletin, 37(6), 784-795.

Van Dijk, W. W., \& Zeelenberg, M. (2002). Investigating the appraisal patterns of regret and disappointment. Motivation and Emotion, 26(4), 321-331.

Weiner, B. (1985). An attributional theory of achievement motivation and emotion. Psychological Review of Economics and Statistics, 92(4), 548-573.

Zeelenberg, M., Nelissen, R. M. A., Breugelmans, S. M., \& Pieters, R. (2008). On emotion specificity in decision making: Why feeling is for doing. Judgment and Decision Making, 3, 18-27. 